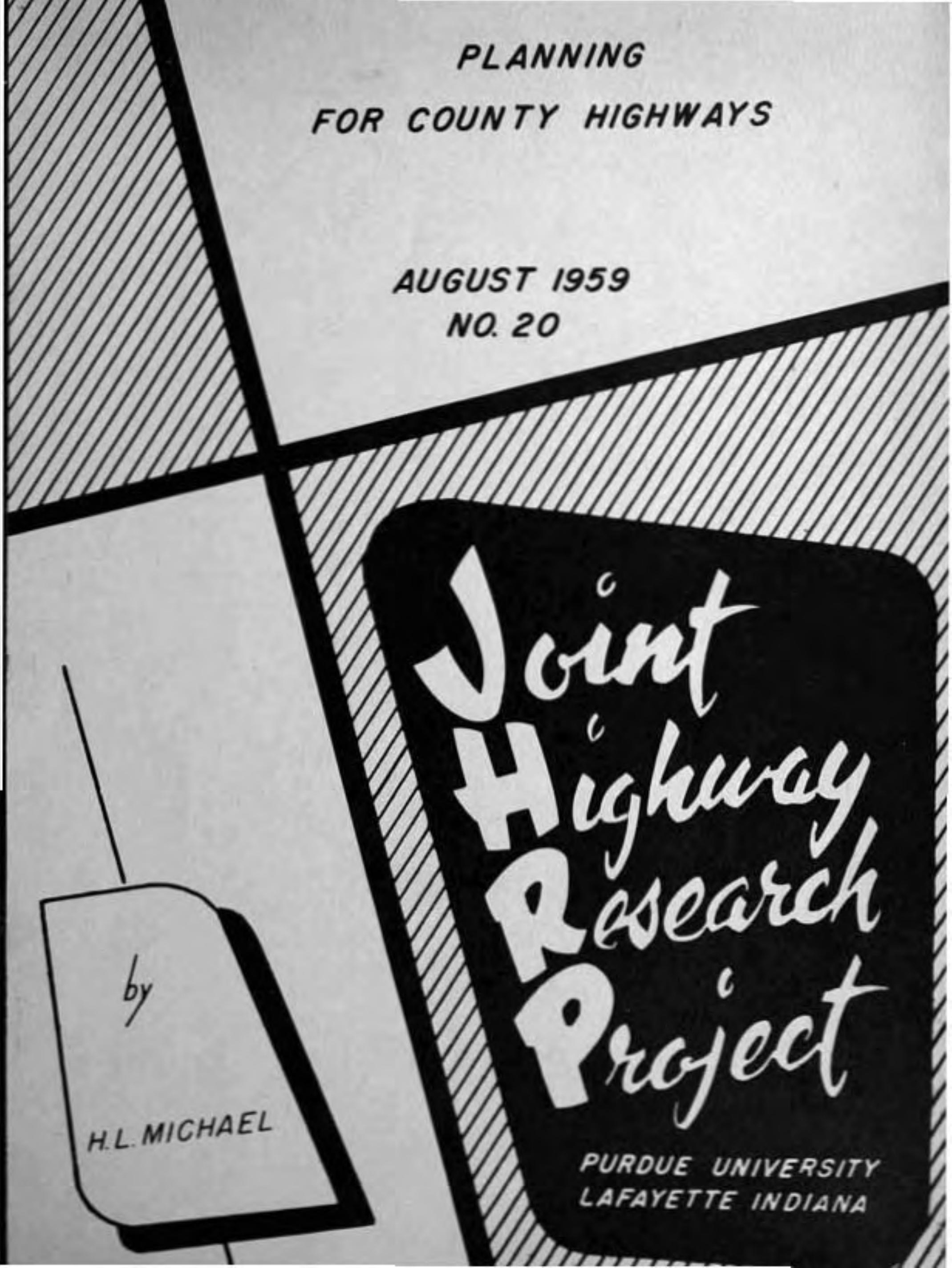


Techrical Paper.

PLANATIO POR COUIIY IICENaYS

202

K. B. Woods, Directer

Joint Bl.ghnay Racearch Projoct

Frol, H. Io Michael, Assigtant Diroctor Joint Hiftury Roeaareh Projoct

August 5, 2959

Pi] $8-6-5$

Project: $\mathrm{C}-36-54$

Attachod is a technical papor ontitled, "planntug for County Highways." This paper was prosented at a joint session of the County Connisstoners, County Auditors, and County Road Supervisore at the Ammas, Purdus Roed School in 2959 by Barold Lo Hicheel.

The paper is a surracy of the regearch activitios of the Project in ths area of county highay claselficistion, road inventory, eounty highay geonotrie standards, priority rstinge, and road and house identirleation.

The paper is presented for tho record and for approval of publication in the Roed Sehool. Proceodinge.

Respectfulyy subratted,

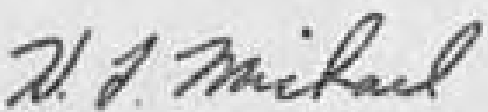

H. L. Mifchael, Aesletant Diractor Joint Hilghray Rosearch Projoct

HIStricue

Attachrent

ect
J. R. Cooper
W. I. Dolch
H. H. Coots
F. F. Havay
G. A. Harking (U. S. Scott)
G. A. Leonards
J. F. Kotaughlin
R. D. 1 hles
R. B. Kay 18
C. B. Vogelgesang
J. I Waling
J. B. Wilson
B. J. Yoder: 


\title{
PLANIIIG FOR COUNTY HITHIAYS
}

\author{
by \\ Harold Io Ifchael \\ Assistant Diroctor
}

Joint Higinay Recearah Project

File: $8-6-5$

Project: $0-36-5 \%$

Purdue Iniverelity

Iafeyette, Inctiana

August 5, 1959 
PLAMIING FOR COUNTY HTGHAYS

\section{INTRODUCTOH}

liore than 76,000 mlles of roade are under ecunty control in Inbians - a responstbilisty for county roed authoritiez which alvost deflea poasurenents. The magnituds of the tesk is indicated, hovever, by taro factorst annual expenditures, which in 1958 totaled ovor 40 million dollsrs, and exploywent, which totaled several thousand parscas.

This reaponsibility places grest problans on the 92 counties sharing the local road authority - problome which are over on the incroaso as our population grows and motor travel miloago spirals upwardo Because oach county has different road needs and different capabilities, local probleme vary. But on thing remains constant: the basis necessity of providing a systam of rocds to meet the cemnde of modern trevel.

Solution of the problem lies in the two-pronged approsch of deterrining the reeds of aach countyta systean and devoloping 8 plan of action to satisfy those meeds. Alort, capable county roed menagersont is a prerequisite.

Can counties organdze their afforts so that the prossing roed needs can bo mat? The answer is fourd in the fact thet many counties have fashioned rethods of managenant which prcduce exceellont results; those counties wero not afraid to discard practices distingulshed only be the fect that they wore long-ostablished.

In those counties which have progressed to eound methods, no doubt exdsto that present and future road demands vilu be mat. Resulte 


\section{Digitized by the Internet Archive}

in 2011 with funding from

LYRASIS members and Sloan Foundation; Indiana Department of Transportation

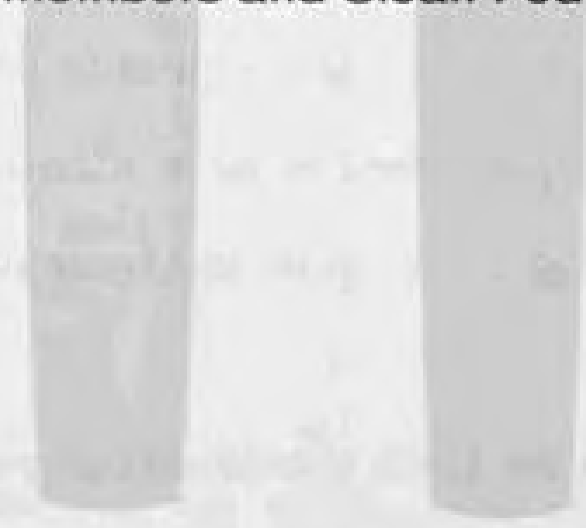


of those sound road prectices have brought prestige to road officials and have won the confldonce of road usors; thus local control of local roads is assurede

Historical7y, when counties were organized they were piven road responsibility by the state legielatures deliberately and for good reason - to insure local control. liany states enacted a legal framow work calling for a county board and specifying the duties of the board and the number of its nemberg. Although provisions vary from stete to state, the basic purpose of the $13 \mathrm{M}$ is the same everywhere: to give to the county board the responsibility for repregenting the people and, in their names, providing a road systam to meet theiv needse within the legal framowork, individual road agencies are givon varying authority to determine the dotails of their operations.

The growth of road responsibility for the county board is easily tracado Years ago, roed building and managerent were relatively stmple; rcads wero primitivo, constructed with wuch the same rethoda and tools as those used by coloniel settlers. Countias at first ware divido od into small road districts. Adjacent proportid owners often mannod the construction and majintenance crevs. The advent of motorized travel changed the type of roads reecied and revolutionized construction mothodso And, over the years as irmrovements vero meds in road equipment, materlals and methods, road building and maintenance became a specialized fiold

These changes, coupled with the necessity for planning roads on a county vido basis, resulted in more and more responsibility being placed on road agencies and their duties becoming increasingly complex. This article to this point has boen taken, with but a fev adsptations, fron a recent publication of the Nationel Association of County Orficials. Responsiblo paoglo in and intereatod in local 
govarnment all ovor this country are saying the sams thing, county-aide planning of rosds is necsesary. But what is county highray planning, what will it do and how do you do it?

County highey planning is flrst of all a mot important function of a county higinay departrent and the one which is soldon utilized by the counties of Indiane,

What is county higiaray pinnring? It is the orderly and continuing collection of Information about county hilghays - including thoir hiotory, condition, use, effects, costs and noede - and the analyals of theso data for the efrecient and econome devoloprent of the higinay aysten through highray classification, priority dotoraination and improverent programe. The objectivo of county highray planning is the establtshment of a natwork of county highnayo capable of accommodating all highray travel, in an orderly, safo, efriolent and economical menner. This is also the objective of the county comanisstoner and county road supervisor.

What are the toals of highwey planning? Thoy are many but let's discuas a fev fundamantal onese A question which county commisaloners are continually baing called upon to answer is thinere are we going to 'black-top' roads this year?" This le one of the most inportant questions to the corclissioner, to the residente of the county, and to the votars of the county. Bvory person, it soens, wants the roed past his houso rblack-toppedt and will insiot that the road past hils house carries a lot of traffic and is in real noad of ilprovoIrent. Can the courissionero hard surface all the roeds whllh they are requested to surface? of couroe thoy cannot - there simply is not that meh money availabis.

Bow than can oce ceterrime which roads to 'black-top' - how can one mles sure that the roeds which are being surfaced are the most 
deserving ones in the cominuity. There is only one way - Hinough county highwey classification and priority detormination, both basod on factse COUNTY HICHWAY CLASSTIFICATION

Most highwey engineers and administrators will egree that it would not only be unnecessary but a.so conpletely undesirsble to build and maintain all county highways as high-typo pavements. Indiana counties have not, nor can they expect to possess, sufficient funds, equipment, materials, and manpower to undortake a hitghay progran of such magnitude. Congequently, it ja necessary that the various highways ba designated sccording to thoir respactive importance. The inportance of a given highway will vary among difierent individuals as their dependence on thet hifhway varies, so it is easential that any cisignation or classification of county highways be made in the public intereste

Before county highways can be clagsified into various systems, it is necessary to determine hot many different syotems are practical and neceseary. A careful consideration of Indiana governmental, financial, and physical conditione has led to the conclusion that three systens of county highuays are most desirable. The degree to which a highway fulfinls the primary pxpposa of county highvays-which is to serve 2ocal traffic, abutting property, and the comanity-is used for classifying the rural road as a county primary highway, a county secondary highway, or as a local servies highway. The vltimate objective of any classification system is to provide a coordinated arrangomont of state, county primary, county secondary, and local service highways which will adequately provide for the present and foreseeable future travel needs of the county. Traffic volume and charactor of use should be major factors in the classification of county highways because naarly all Indiana county highray revenues are derived from highwey user impostso on the other hand, the effect of abutting property cannot be complately ignored because 
of the direct relationship between land use and treffle generation. Community interest is indicated by the service provided by the highway. Thi. service may be maasured by a study of the areas or locations which are linked together by the roado Service routes or special use made of the highway may also warrant consideration.

Only a minimun number of miles of county highways should be placed in the county primary and county secondary gystems. This is essential because with itmited funds, the mileage of routes requiring high design standards must be linitede

Future growth and devalopment mist also be ovaluated in order to provide a coordinated highway plant which will provide for future ag well as current requirementso

\section{Basic Traffic Information is Essential}

Before a county highway can be classified or evaluated, it is essential that information is avallable concorning the volume and character of traffic using the road. In 1937, the Indiana State Highvay Plenning Survey publtshed traffic volume meps showing the daily volume for all county roads in almost every county. Current mape may be developed by collecting volume deta from a fev properly selected field stations and by a study of the development which has occurred since 1937. The latter study requires observation of all arsas where development is presently occurring. Information on the present charecter and wear of roed surfaces is also often an indicator of traffic volume. Some roeds have been clagstified as Federal Aid Secondary Routes for roasons of their Importancs and information on this System shouid also be obtained and utidiszod. 
Average daily traffic volures are generally used to provide Ifmits for design standaxis. One comron practice for locel roads 18 to provide reasonably high standards for average volumes in excese of 400 vehlclea per day, intermediato standards for average volumes betveen 100 and 400 vohicles por day, and lowor standards for average volumes loss than 100 vehtcles par day.

Doterminats.on of Abutting Iand Uso

The necessity for any county higinay is directly related to the panner in which the land adjacent to the hifhway is used. Thus, roeds passing through highly productive fasmland may have high seasonal, but low annual traffic volutas; while roads through relatively poor famaland, Which has been subject to suburban residential deviloparent, may serve high daily volumes of traffic. Cultural institutions such as schools are handicapped if the highways serving them aro impassable mich of the time. Roadside parks and other racreational faciltties tay be used by highis concentrated traffic volumos only during favosable weather conditions, thereby cauging greatly fluctuating traffic volurres on their access roade.

Information concerning the frequency and type of roadside devoloprent is obtained in the field and conpered with existing recordse

\section{Datermination of Cormsunity Interest}

Coramity interest may be indicatod by the area or locations connectod by the highray. A rosd may sorvo as a vital connecting link between a omall comanity and a large city or a mejor traffic erteryo Another rosd may caxyy high volumes of traffie batween two state routos or connect an important or productive area with a diatribution center or 
access highray. This information may be obteined from a study of local land ugu mapa, population mps, and a lnovisedge of local conditionse

The inportance of the various types of sorvice routes such as school or comreretai bus, rural mal, rduk collection, or hesvy trucking routes using the highray varios in each county. Local school, corterciel bus, mil, truclding, and other offlcials ahould be consultod for gervice route inforration.

The County Prinary Systen

Certein highrays, because of thoir loctition in the county and method of construction, may have average dajly trarile volumes ranging from about 400 vehiclos a day to soveral thousand voliziclea a dayo. Thase roade may serve to connect a large city with a sallor rural corsanity, or thoy mey serve as a vitol comnscting Iink betwoen two state highrays or to connect highly productivo aroas vith the highay. Such highrays are the type to be considered for incluafion in tha county primary system. This systan should constitute $10-15 \%$ of all mileege in the county.

\section{The County Secondary Syeter}

Roads vilch carry traffle volumes ranging from 100 to 400 vehiclou a day genorally belong in the county sacondary systers. The eervice provided by the rosds, scch as connecting less important coumunitiss with each other and/or wth higher clessification roads or highways, should also be considered. This syotem, too, should be cormplsed of 10-15\% of all. atl laage in the cotnty.

\section{The Iocal Service Systom}

A11 reraining low traffic volume rural roads, which, as tho dosignation implies, carry low dally volures of usually lese than 100 
vehicles per day and which primarlity serve oniy the local area, aro classed as local service roads. The oe roads, in general, do not directly serve as many people nor as mich of the county and, consequently, may have a lower design standarlo.

\section{VIgo County Highvay Claasification}

Purdue University, through its oxtonsion services in the Joint Highway Reasarch Project, rveontly completad a county highrey clessification study for Vigo County. The resulting County Higinay Classification Syston is shown in Figure 1 and the System vill be described as an exanple of county highnay claseifieation.

V180 County with an estimated 2958 population of 105,160 is served by approxiatoly 100 doloe of otete higinay that essentially rediate from the county soat of Derre Heuts which has an egtisated population of 72,890 or about 70 per cont of the total county population. In goneral, a etate hi ghvay is within a distance of eight miles or less of ail county residents. Supplonenting this system is the county highay systea of approxdmately 1000 miles. The County Primary Highay Syetos

The prisary highrays are so dogigneted bacause their location In the county, type of constructicn, and character of trafric use rake them logical roctes to bs devolopod for tho flow of high voluras of rissed traffic. Nost of the Vigo County primary highwaye are radial routas, which either connoct comsunities within the county or cossunitieg outside of the county to Vigo County cormuntises. One routa is essentially a oireunforential highway around Terre flaute on the north, east, and south. This route, with its primary coanections to Terre Haute, should aseist in distributing the traffic to and from Terre 
Haute to other primary and eecondery county highways or the state highwayb. It also serves the najor areas of development within the county. Of the 2006.5 milos of total rurel highwaye in Vigo County. only about 89 miles or 8.9 per cent of the total are clsssified as county primary highways. Thsee highways should be devoloped to relatively high standards, and the rosdwey surface, shoulders, Fighteof-way, bridgos and traffic control dovices should be dsgignad to provide adequate eervico and safoty for tho motoring public, In general, the county primery highrays will be the preferential county rosds for traffic flow purposes and each major intersection must be investigeted for proper signing。

As of February 1959, 62 millos or 70 per cent of the County Prinary Highrey System were constructed with hard surface roadway varying from low type bitumincus surface to high type concrete pavemonts. The County Secondary Highway Syotam

The County Secondary Highwey Systom of about 143 milea or 24.3 par cent of the rural mileage is so designated becauge these roads generally gerve as feeder roads to the County Primary and State Systems and csrry loss traffic than the county primary hishways. The current treffic voluna on roads in this system is usually nore than 100 vehicles per day. Thay also cunnect small rural communities with each other and/ ov with county primary or state higlways, vitinately, as traffic volumes increase because of continued developrent in these areas, some of the rosds in this syeten may warrant inclusion within the County Primary Syetom.

As of Fobruary 1959, 57 milos or about 40 por cont of the County Socondery Highway System wero surfaced, in general with an intermediate 01. Low type bituminous mix. 


\section{The Local Service Highway System}

The Loca] Service H.ghway System is composed of the remaining 774.5 miles of the rural rosds in Vigo County. This System comprises 76.8 per cent of the total county road mileage. Approximatoly 36 miles or about 5 per cont have beon surfaced with bituminous mixtureso

The se roads, as tha name implles, eerve local azeas and usuatis carry loo volumes of traffic of less than 200 vehicles per day and frequently less than 50 vohicles per dey. Road sections in thls Systrm do not sarve as many people nor as much of the county as do roads in the other two councy highway systems. Consequently, local service highways need not be butit to as high standerds as the roads in the County Primary and County Sacondary Systomo

General Commante on Cleasification

A relativoly small mileage of county roads has been clasafisid In the County Primary or County Secondary Systems because this mileage, combined with the state highweys, is adequate to serve the neede of county rosidents. These systems of highneys should be developed rapidly to adequate standsrds. These are the roads which shovld be given naximm consideration for improvement during the next few yearse A sunmary of the miles of road in each System in Vigo County as of Fobruaxy 1959 is given in Tablo 1.

\section{THE GIGINAY INVENTORY}

Following or in conjunction with the classification study, an Inventory of the county hi.ghway system needs to be mada. An accepted and valuable business practice is that of conducting periodic inventories in order to deternine the current status of the business. The county highway administrator, like his connercial counter-part, should have a 
Table 1

Clasalfication of County Highnay in V1go Courty

\begin{tabular}{|c|c|c|c|c|}
\hline & & Percent & Hard & rfacod * \\
\hline C)assificication & 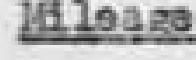 & Total Kileape & 51.10080 & Per cent \\
\hline County Primary & 89.0 & 8.9 & 62 & 70.0 \\
\hline County Secondary & 143.0 & 14.3 & 57 & 40.0 \\
\hline Local Service & $77 \mathrm{~L}=5$ & 76.8 & 36 & 5.0 \\
\hline Total & 1006.5 & $100=0$ & 155 & - \\
\hline
\end{tabular}

As of Pobruary, 1959 
vital interest in knowing the present status of his business- the county road system, Most citizens have definite opinions concerning what is wrong with the county roeds and how these faults are to be corrected. Consequently, when county road edninistrators are forced to allocate funds on the basis of opinions rather than facts, they can usually expect varied amounts of criticism from disappointed petitioners.

Generally, records describing the existing physical, conditions of the county road system are inadequats and inaccurate. It is therefore essential that the initial. inventory be as corplete and precise as possiblo. All peritinent information--such as highway nunber or nane; right-of-wey, shoulder, and rvadway widths; roadside culture; type and condition of the pavement and surface; topography; horizontal. 2lignment; passing sight distance; stopping sight distance; safe driving speed; and gredient-should be recorded. This record will not only provide county road adninistrat,ors with a factual record of essential road information, but the location and extent of critical conditions are readily evident. It is imperative, therefore, that the county highways bo properly identified through an accepted rural road identification system.

\section{Inventory Procedures}

One or moxe throe-man "logging" crews are used to obtain the factual cata such as widths, types, otc. One "rating" party mey than coimplete the information, such as condition and adequacy coments, for a.ll the highways. The number of logging parties depends on the available manpower and time, but should be kept to a minimum in order that comparable information may be obtained. Only one rating party should be used to insure the relative evaluation of all highways. Forms for the inventory cen be readily developad for tha specific conditions of each studiy. 
The noxt step in ordority developmont of the county highray system is the development of standards (Design Standards) for the construction or reconstruction of roads and standards of adequacy (Tolorable Standarig) by which the adequecy of an existing roed can be mes.sured. Al.though the inventory will. provide the hightay administratore with facta about the county roed natwork, thero atill may be considerable question as to whet conditions are necessary io provide reasonably satisfactory service, Thus, the adninistrators are feced with the need for a sot of scales with which to nasure the abilitity of a section of highvay to provide gstisfactory servics. The tolerable standards are this get of scales. Roadg which do not meet the tolerable standards aro inadequate and in need of improvement and when improved would be constructed to the design standaris so that they will continue to be adequate for many years to cone.

Through cooperative action of many agoncies and organizations, tolorable and design standerds have been established for all types of rural roadso. These standards wero studied and in some cases modifled so that they represent values which, if followed, would rosult in econouy, userulnass, and longevity in highray improverents. The tolorable and design standerds recommended for the three county highway classifications are shown in Tabls 2. All standards shom aro minimum.

Some county officials may hesitate to approve the adoption of design standards such as these bucause thoy may appear to be too higho It may be remembered, however, that nuch of the present congestion on county roads mey be attributed to similar arguments of years ago, with the end result that funds were expended on the basis of design standards which 
Table 2

Minimum

Tolerable and Design Standerds for Fural County Roads in Indiann

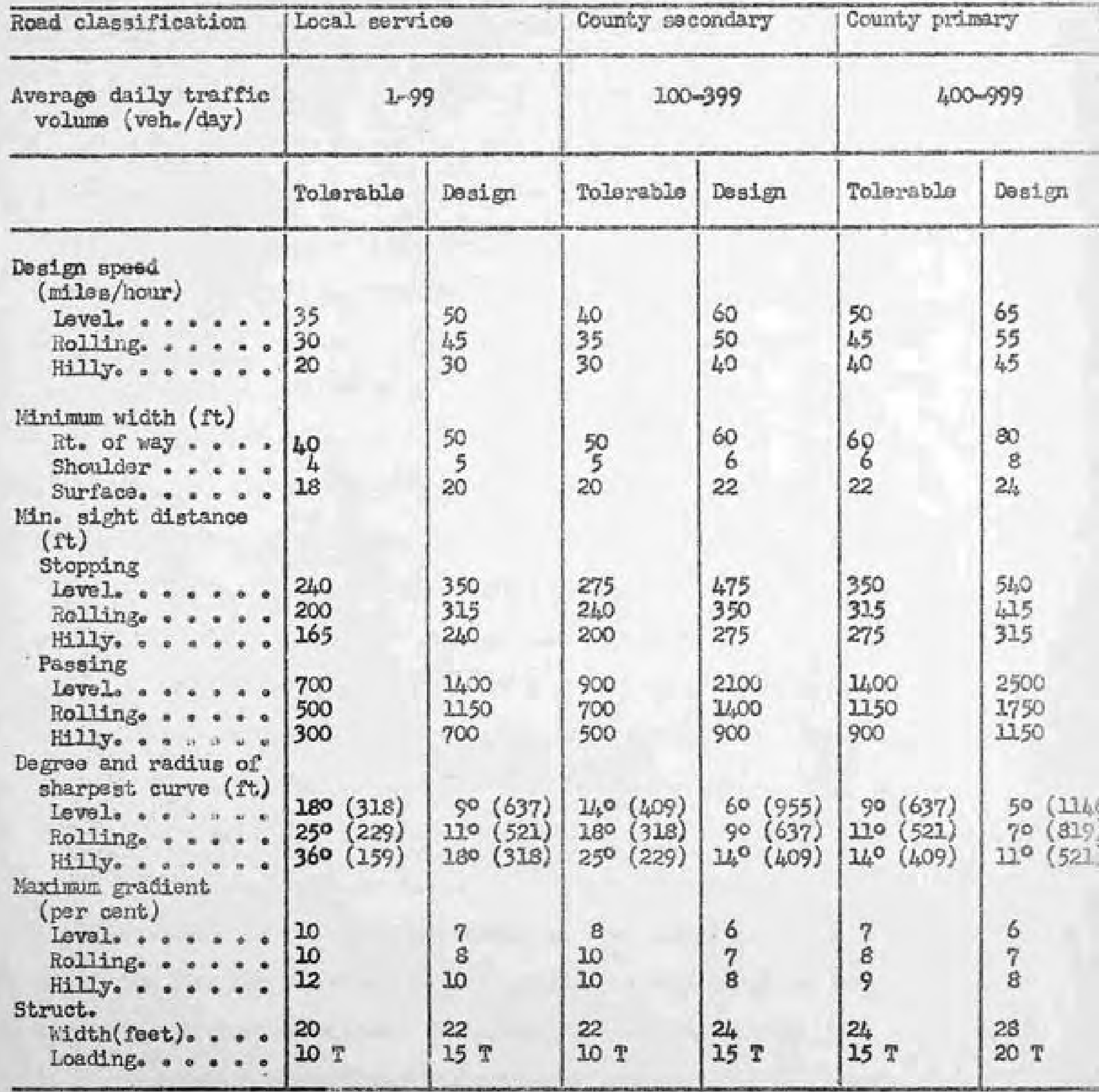

Wotet Standards for the pavement aro dependent on many factore which vary locally. Compotent professional advice must be obteined to determine this atandard. 
the county officials "thought" they covld afford. Consequently, the cost of providing an adsquate highray is now mach greator. The multipla coats of delay and lack of safety which result each year whilo insufficient standards are utilized must also be considered.

\section{DETERMIIATION OF PRIORITY FOR IIPROVBMENT}

With an inventory of the rosde (what you have) and a eet of tolerable standards as to whet is adequate (whet you should have) the next etop is a comparison of the two. Such comparison will shou you What the noeds are for Improvemant on the county roads, in other woxds what Improvements are nooded to bring the highrys to adequacy. Such comparison will show that there are more nesds than there is money to eliminate them in one year. The problem thon becomss ons of deiernining which roeds are most in noed of improvenent - which roads if imoroved will provide the naximm in benefits to the most persons.

The next step, thorefore, is to assign a priority of inprovement to the many sections of road which need inprovement.

When one is deciding which of several road sections are in the groatest need of inprovomont ho probably asks himself two questions:

1. Which road is most important to the comanity?

2. Which road is in tho worgt condition?

Then his thanling continuas. If Rosd $A$ is the most important to the corraunity and in the worst condition, then flosd A should be on top of the list for improvement. But usually the most important roed is not in the worst condition. The problem is not that simplo.

A method commonly used to guide the road official in answering these two questions utilizes priority ratings. The mothod utilizes facts about the roads to supplement the good judgement of the road of ficial. 
It pulls togother, in a systematic manner, the facts which will contribute to his judgement.

The details of priority ratings are not difficult. Basicaly each road is evaluoted along vith all others in each highray syatem and esch rosd is reted - given a mumareal reting - a to its irportance as a county roed, as to its adoguacy of condition, and so to its safety. Thoso musarical ratirgs are rade froa a study of the facts obtained in tho inventory and a corparioon with the design standsrde for roeds within that systam

Lot's Iook at som exaraploet - the Importance Rating (Sometimes culled Service Rathing) rlxst of all.e

Bach road in the county is given an importanco rating - with the most 1mportant couniby road givan the highe ot rating and decreasing ratings givea to all other roads dopending on thelr importance. The Inportance of a county road is avaluated from the facts by measuring the service provlded by each rosd. This is measured by tha volun of traffic using the road - cortainly a road carrying 600 vpd is more important than one carrylng 200 vpd - and by the number of servico routes (school bus, nes., producs, etcs) it carries, the number of proportioe it serves (the hotes and busineases along 1t) and its use as a comecting Jink betweon two lmportant locations (such as two rural commanities). Bach of the roeds - from the facto - is given a numarcal value for traffle volum "route service, number of properties served, and connecting link service and thoy are added for each roed to obtaln a numerical Importance Rating. The most important road in the county will roceive the highest rating. 
For examplo, a "perfect" highray (the most important one in the county from the standpoint of sezvico), will accumulate ite Inportance Rating of 50 as follows:

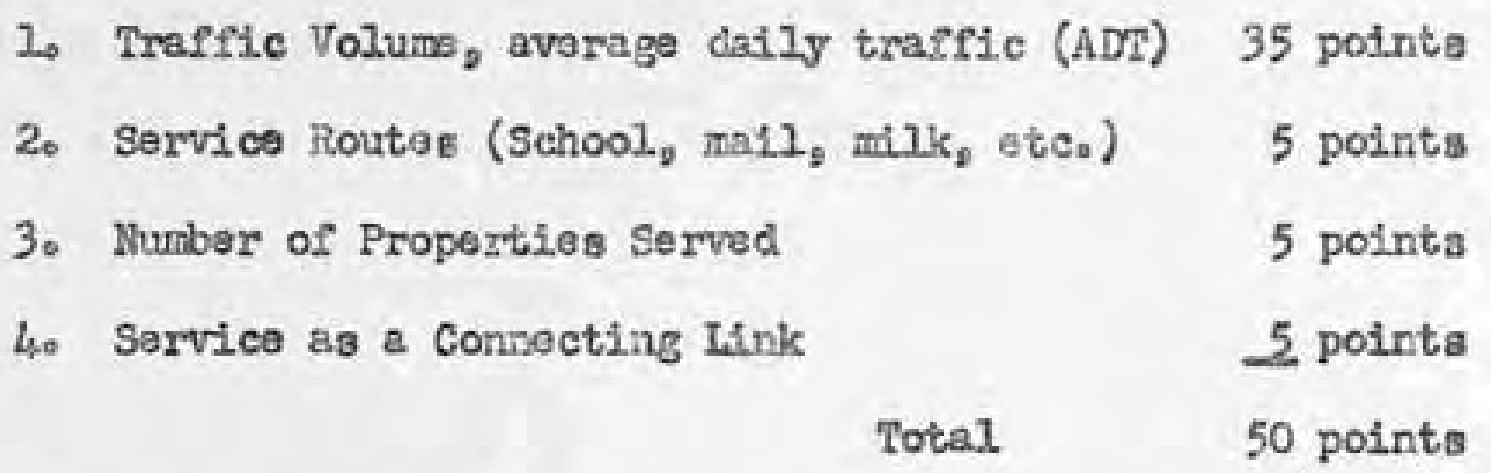

Bach other road in the county would bo evaluated sinilarly and the various factors 11 sted above would ba fiven a numarical value on the basis of its importance as compared to the "perfect" (most important) road. The numexical value of the least important rosd may be one (1) or glightly higher.

Bach roed is then also rated as to its condition and safory from the facts of the inventory and from the standards developed. Under condition, for exemplo, such road eloments as right-of-way width, surface Width, alignment and gade, smoothness of surface and condition of shoulders, drainege and pavomsnt structure should be rated with each element which is adequate receiving the naximis number of points for that element。

A rating for safety is then also made by coneidering those road charecterist1os whsch result in eccidents. A road, for exarmle, whitch has many sharp curves, poor sight distancs, and meny entrances and exits along it would be rated poorly on this factor. If accident records are available for a number of years they can bo used to make this eveluation. Additional elements can be addsd to the above and rated if desired. The weighting of these factors may perhaps be begt 
11lustrated by Indicating how the "perfect road" would accumulate lts Condition Rating (sometimes callad Road Reting) of 100 points.

1. Widths (25 points $\max$ )
a) Bffective right-of-way width
10
b) Rosdbed vidth
5
c) Surfacing (or traveled way, if ungur
faced) width
d) Varginal clearance
5

2. Als gnimit and Grads (15 pointa pax.)
a) As affecting ssfo or attainable speod 5
b) As arfocting stopping si ght distanco $\underline{10}$

3. Surface Characteristics ( 10 points maxe)
a) Smooth riding evaluation 5
b) Raveling evaluation $\underline{5}$

4. Structural Adequacy ( 35 points mare)
a) Shoulders
b) Drainage 10
c) Pavement structure
$\underline{20}$

5. Safoty (15 points max.)

Maxima total $=100$

We now have an Iportance Rating and a Condition lating for each roade These taro ratings must than be combined into a Prlority Rating. 
This priority rating should toll us the roistive importance and condition of each roed in the county. Tho most fruportant rosd if It were in the worat condition should be at the top of the 21st. The least inportant road which is in good condition should be at the botton of the 1ist.

Present prectice is to combine these two ratinge by use of a formule which provides that roedo of lok importance rating regardless of condition rating have a lou priorlty rating and that roads vith high condition ratinge rogardlees of the inportanos rating have a 100 priority ratinge A chart which has beon propared for this purpose and which vas proparod for the Allon County otudy by the Jofnt Hil ghay Research Project 1s ehom in Figure 2, On the chart the Inportance Rating is reforred to as the Sorvice Rating and the Condition Rating is called the Roed Rating. It an be used by other countles if the roudram number of points assigred to the Importance (Servica) and Candition (Road) Ratínge are 50 and 100 reopectívely.

The result is a priority rating for esch section of road in the county - in othor words a listing of the ordor in wislch the roads need ifprovorment is provided - the questions of whleh is the moet inportant roed and which is in the worot conditfon have been answored by factes. 


\section{ROAD IDGITIFICATIOH}

Another stgn of good county road management is the exdistance of a eound and orderiy gystom of county highray 1 dantificution. Descriptions of roal ostate in both urban and rural aroas have follonad accepted prectices for reasono of legality, omerahip, tasction, and othere. In addition, the naming of streets and the nunbering of houses and business units in urban areas have been a necessity and a convonience for many years. Usualiy the naming and mubering have beon dom in an orderly and systomatlo manner, but littlo has been done in rural arvas oxcept for the naning and, nore rocent17, the mimbering of the princlpal rural higinayle

The repid developrant of motor vohiclo tiansportation and the desire for more effectivo rural develogtment and botter coumunity gervices in the countios of Indiana have increased the nesd for an ordsrly mothod of Identh fylng $10 \mathrm{cel}$ rosds and homes in rural areas, Among the conmunity servieou to bonerit from such a procedure are the publie utslities, fire protection, modical and vetexhry ald, all types of delivery routes, and others of sindlsr character. Improvement of tho accounting and cost control methode of the county highway departinent Is another benafit to be received through better identification.

A county road system that idul provide for better couraunity sorvlces and the gonoral inprovewont of the area will require proper 
Idontification of local roads and rural dvelling units and an effective syaton for accountirg and cost control.

\section{tiniform Syatan is Dosirablo}

A unlform aystem of Identiflcation and control is desirabia. Bach county should serve as a besic unit, but idontiricetion mothods should be unifora for e.l1 counties in the state. If the specifications and mathoda are unfform, tho residonts in ous county can essily interpret tha county road ariding and civelling unlt numboring in adjacont or distant countios

Tho estableshent, uee, and eveluablon of accounting and cost control proceduree that are unifom throughout the state, will facilitate tha vork of the Stato Board of Accounts and agsiot the county offycials who are responslble for the planning and progrentuing of an effective syatom of rural roado.

The idontification and location of county roads relative to establishod base lines in each of the 92 countios of Indisan mey be accompls ahod In a mannor aimilar to that usod for state highrays, but cortain basic charaetarlstice of the local-road problem mute bo considered in the devologment of the procedure.

In gonerel, the cheracter of trevel on the local-roade in pradorinataly intra-coursty, but it includeo som intermosunty and interstate movemant. Nost of this iocal-road travel is to-end-from the county seat, or othsr trade areas in the courty, and in adjecent countiea. The patch-iork of short-section and variabla-direction local-roads doos not alveys land 1tsolf to the dovelopront of continuous routes within a county or botaven countlate 
Thus, it is desirable that the rethods used for identification and rolative location of rosds and in the numbering of rural horres should be clogoly associated with the charactor of the iravel on these soads, be county-ide and uniform throughout the state, provide for continuity with adjacent counties when possible, and eraloy ongineering survey techniques.

\section{Iand Survey Principles Pollowed}

Fundamental gujdes in the developuent of a uniform system of rural road marking and tholling unit numboring are found in the principlos of the U. S. Land Survey。 The State-Vice Bighry Planning Survoy, conducted in Indian in the late $1930^{\circ} \mathrm{g}$, used these basic principles in the devolopment of the Coneral Highway and Transportation Maps of the 92 countioso In this study, sivdiar principlos were used to establlein the bago lines nseded in tho devoloprent of the inethod for rural roed and homo identification。

In applying these principles ro naming and numbering, each county of Indians is divided into four quadrants, as illustrated in Figure 3, Recormended Base Lines for Fural Rosd Herking. The base lines of the quadrant coincide with a projection of the Range and Township line intersection mar the center of each county.

Figure 3 iliustrates how the intereections of Range and Tomship lines near the center of aach county In Indiena coincide with gection lines, and, when extended to each county boundary, they form the baselines of the North-Bast, North-Nest, South-Bast, and South-Weat Quadrants of the county. Many of the intersecting range and township lines are relatively close to the county seats, and when fearlble, 
coincids with the base lines of adjacent counties to provida for continuity。

This continuity is also illustrated in Migure 3 whers the Second Principal Neridtan forms the ranga base lines in Clinton, Boone, Hendricks, Morgsn, Monroe, Lawrencs, Orange, and Crawford counties. It also shows continuity of tounship baso lines in IaPorte, St. Joseph, Blkhart, IaGrange, and Steuben countise. Additional exarules of continuity may also be observed.

If roads are located along all or pazt of the eastmesi and north-south base lines, they aro designated as Division Road and Vartelian Road, respectivelye

Rosds Numbered by Distance

Section line roads and others paralleling these base lines form a rectangular coordinate systen with Division Rosd and Meridian Road sorving as base linos, as illustrated in Figurs 4 , Examples of Road and House Designations. The numbers assigned to thess gection line roads and other parellol roads reprossnt the progressive diatance of each road from the base linese

The firgt section lina parallal to a bage line is designated by the number 100 , folloved by the letter of diroction (N, S, $\mathrm{B}$, or W) from the bese line. Tnis, the first section exgt of the north-south 1ine (Mertidian Roed) is designatsd as $100 \mathrm{E}$, and a rosd along thei section Iine is dosigatod as Rosd 200 Eo Sirrilaxiy, a section uno raed 3 miles south of the east-hest base line (Diviolon Road) would be destenated as Road 300 S。

Roade parallel. to tho bace In roe rods, but loceted between section lines, are assi ned tireir relative position and number by dividing each section (about ore aile) into one-humdredths of a mils. 
Progregsive nunbers are assigned to hou the position relutive to sections and approximate distance fron the base lines. Trus, a rosd along a quartersection $1 \mathrm{im}$ that is about $13 / 4$ ad las scuth of tho east-uest base line (Division Road) would be designatod as Road 1755.

\section{Spocial "Problat" Roade}

Diagonat, curring, and jogging rosds prosent a problen beceues choy clkange direction, and, thus it is difflcult to essign a distance nubir or direction latter to all segrents of the roade. The folloaring goneral principles should be uged when opplicable:

2. Roads with irregularities of loss than one-tenth of a mile fron the nornel vest-west or north-gouth location should carry the eawe nurber designation throughcut, as il huatrated by Rosds $300 \mathrm{~S}$, $200 \mathrm{~kg}$, and $225 \mathrm{~S}$ in Pigure to

2. If an IndividueI streaightm-lino jog in an east-wost or north-south rosd excueds one-tench of $\mathrm{e} a \mathrm{mi} 1 \mathrm{~s}$, it should bo considered as a aeparate road and assigned a mumber, as 11lustrated by Road 96 wo

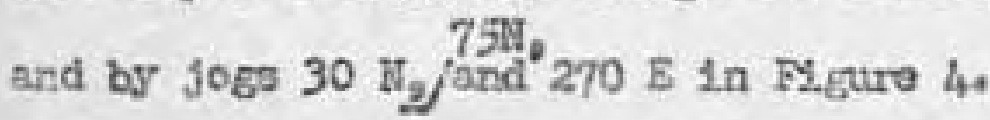

3. Ioop rosidg forted by allgit devlations dine to topographical. and cultural barrieso ghonld be considored as strai git roode, as 1)Inetrated by the 200 p formed rear the intereoction of Road 250 vith Rosd $300 \mathrm{~W}$ in Riguro 4 .

40 Roads vith irregularitios, axcept for a singls straightline jog, exceseding aso-tenth of a milo froa the nornal eaot-west or north-aouth location should be narred, as 111ustrated by Pedan Roed, Loop Road, and Kline Roed In Mgure 4o 
Whare an asst-west, north-south, or variable direction road colnoidas with a road in the State Highray syotom, the legend of the intersoction gign should aloo include tho number of tho Stato Highrey route.

Each county should muber (and nars when neceseary) all mods xithin the county and tho county lins roads (and houces) on Itesouth and rost boundaries. Counties adjacsnt to Ilinols, Midhigan, and Ohdo may assign the name State Ine Rood to boundary roade.

\section{Similar Systen for Elouse Numbero}

Houso mimbering is eccouplished through applicats on of the basie grid syotan ueod in road identirication. Thus, the house numbering systam givea the relative poeition of the rural residunces to about the nearest one-hundrodth of a mlile froat tho seciton linos.

It must be romantered that the lnst two dfgits of a houge number rufore to hundredtbs of a mlile in a sectlon and that digtis to the Ieft roprosent eaction lines to the neareat whols mile. For examplo, the numbor $2225 \mathrm{E}$ means that the house 1 s about 12 and $25 / 100$ milas east of the base lino. In this examplo the difection letter designation in the houge number, whon combined vith the direction lotter dosignation in the roed nuber, incleatos the quadrant of the county in wich the houns is located.

Houses along east-west or north-south roade could be assigned true coordinate positions, but thoy vould be eagior found if numbered aa followe:

1. Odd-hundredthe $(29,201,325)$ are sasignad to houses on the North or Bast asdo of a roed. 
2. Ever-hundredths $(30,202,324)$ aro assigned to houses on the South or Wost aido of a road.

Buanples 1-4 of Figure 4 111ustrate the mothod of nurbering housos cn roads classifled as east-west or north-south roads.

Houso rumbers on diagonal, curving, and jogting ronds follow the distanco and position concept used in the location and mubering of roads, as 11lustrated in Figure to The rectangular coordinate systen is applied with equal fecilfty to rouds of variable direction. The application of this systen, calibratad to the mila, tenth of a rille, and one-hundredth of a wile cives the distance and direction of as house relative to the bese lines.

Exarple (5) of Figure 4 iliustrates how a house at that position on Padon Rosd is assignad the mubor 215 13/4 Poden Rosd. The 22 indicates that the dralling unit is about 21/100 md?s south of Division Rosd, and the 234 indicates that it is about 1 and $34 / 200$ miles west of Varidian Roed. Exanples $(6-12)$ aleo illugtrate how houses on variable direction zoads are assigned rumbers by this nothocle The asuigmant of odd or even numbers on diagonaj roads, as preacribod for numbering houses on eastowost or north-south roads, is not practical. The true coordinetes, havever, Elve the position relative to the beop lines and parnits easy location.

\section{Minsures Standerela Ior Road Stige}

Road stens shouin conforn uith stancisrds surgestad in the mannal on Undform Trufric Control Devicos for Streets and Bighays", The follooring mintrun standardis aro suggestad to provide for econong of dasign and for uniforatty, legibility, and visibility of the sigast 
Color and Visibility of Sign

Black letters or numbers on a white background sre recomended. The signs should be reflectorized, and at critical intersections they should also be illuninated.

Legend

The letters or numeralo of the primary lagend should be at least 4 inches high, while those of the secondery legend (supplementary name) should be at least 2 inches high. The size, shape, and spacing of the letters and numerals should conform to the standards available from the Bursau of Public Roads.

Sign Plate Specifications

A horizontel rectangle, with \& minimus height of 6 inches, is required for slgns limited to a primary legend. The height must be Inches when a secondary legend is used. The length nay vary from 28 inches to 30 inches, denending upon the legend. Sheet iron or steel signs should be 18 gage or heavier, depending upon size and rigidity desired; other materials should have sufileient rigldity. Double-faced aigns ghould be used.

Kounting Helght

Road-3ide conditions will, in general, have a oignifleant effect upon the mounting helght of the signs. The signs should be mounted on a fixed metal post. In rurel areas the lower edge of the signs shovid be not less than 5 feet above the maintained edge of the road surface; in suburbsen or other aroas under the jurisdiction of the countias, whare obstructions mey ba caused by parking, a minimum elevation of 7 feet above the road or surb is required,

S1gn Iocation

For intersections with average daily traffic volumes in excess of 250 vehicles per day, signs should be placed on diagonally oppoaite corners vo that they w112 be on the far right hand side of the intersection 
for trafrie on the more inportant road. Signs indiosting both rosde should be erected at each location. In general, they shouli be placed not lase than six foet nor nore than 10 foet from the maintained edge of the road, and should be placad as elove to the cornar as practicable, facing trafrie on the eross rosd,

At intorsections uth lass than 250 vehtelos por day, signs Indiesting both rosis should bo' placed an the one cornor with the greatest vioibilsty.

A priority of erecting signs should be adopted by tho courityo Roads which perforn the graatost comminity service should bo rasked prlor to those of lasser inportance.

\section{Finaneing Rosd Varlding}

The cost of adaguate sidens and road meridags and of propor maintenance is astirrated to be about one or two par ont of the annual county budgot for highaye. This Ilnancing ray bo aeconplishod by county appropriation of funde, serrico club project, costarcial developmint, or other mathods.

llaps Indleating county road markingo and house nurbera ghould be propared in accordance with the ostablished principlas. It is reasonablo to assum that divectorios of rural residonte might sorw a useful purpose and that the sale of maps and directories could atd in finanding tho projecto

All records of operation, construction, and maintenence of county roads should bo in accordanco with tha prineiplos of rosd merlding and house murbaring. Accounting and cost control records thst are oasliy applied to the county road or parts thervof are escential to adoqutts road plenning and propraming. 


\section{CONCLUSION}

Many county offleisls in discuasing county highvey planning seg, Wle haven't onough money to do ail thesa things", But county highway planning is aot expensive end it uill save the county thousands of dollars in the ruture. In fact, when funds are in short supply is the most logical time to plan better, to use the funds avallable better, and to avoid costly errors - it is the time for a high degrea of effiolency.

Sone county offieials nay feel they are doing the things diseussed in this peper. If they are, they are doing good county planning and they can answar yes to the following questions:

1. "Are the roads of your county classifled? That is to say, ore they dirided into groups according to inportance or purpose, whatevor these groups may be called, so thet a basis is ostablished for priority of improvanent, stendards to be achiered, and mathod of PInanee?"

2. "Io your county road systen inventorled? That is to say, does the courity lmou exaetly what rosd systom it has, and Borething about its condition, and is this Snformation kept up to date?"

3. "Does your county heve a plan and a program, are they boing continuslly revised, and is thera sufficieat record keeping to perait planning and progranging with realies?"

4. "Is thece a definite set of standards to which various types of roed faolifities wlll be construeted?" 
5. "Are your county rosds Adentiried? That io to aty, are they adequately nemed and properly marked according to a. logical organized systea?"

If the answer is yes to afl these guesticns that county does have tha basie tools of good county highway roed nanagement. If the answor is no to any of thess questions, the county ofrleisals of that county ahould consider whother thay are anaging the highrays of that county as thay should bo managed, 


\section{ACKNCWL BDGEMENTS}

The material eontained in this paper is an adaptation of wuoh interial which has proviously been publiohed. It hes been coubined here to sarve as a ready reference for those concernod with highray planning: The author acknovledges the work of the following individuals snd their Indieated publications and wishes to give the thoir due crodit for the vaterial oontalned in this peport

1. County Rosd Xanagenent Relations, Roport of the Speosal Joint Comititee of County Ccomissioners and County Bhgineers, tational Association of County Orfleials, Kashington, D, C iv Augusta 1958.

2. Prorities for Local Rural Poad Improvanents, by James $\psi$.

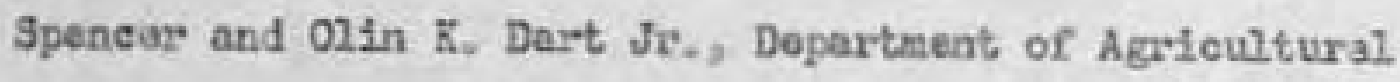
Engineering, $\mathbb{H}_{\text {. }}$. S. Colloge of Agreulture, Comel1 Univera1ty, Ithaca, N. Y*, Septamber, 1957.

3. "Improvenent Propity Ratings for Local Rural Roads in Indiane", by J. B. Baervald, Progeedinge of the Highway Research Board, Vol. 35, pp 3e-62, 1956.

4. "Progreas Roport on County Road Karking", by A, R. Branhin and J. B. Beorwald, Proceedinge of the 4 Oth knnuel Purtue Roed School, Extension Ser1ou No. 86, Mo2. 38, 110. 4 , pp 117130 , July, $1954=$

5. nV180 County Highang Classirieation", by R, D. Miles, unpubliahed report of the Joint Highay Research Project, Purdue Dniversity, Herch 25, 1959. 
6. "A Case for Inpuovement of County Righway Administration", Spacial Report Prepared By Frank C. Mclliater, Diractor Transportation Departanent, Indiane, State Chanber of Coamerce, June 1958. 


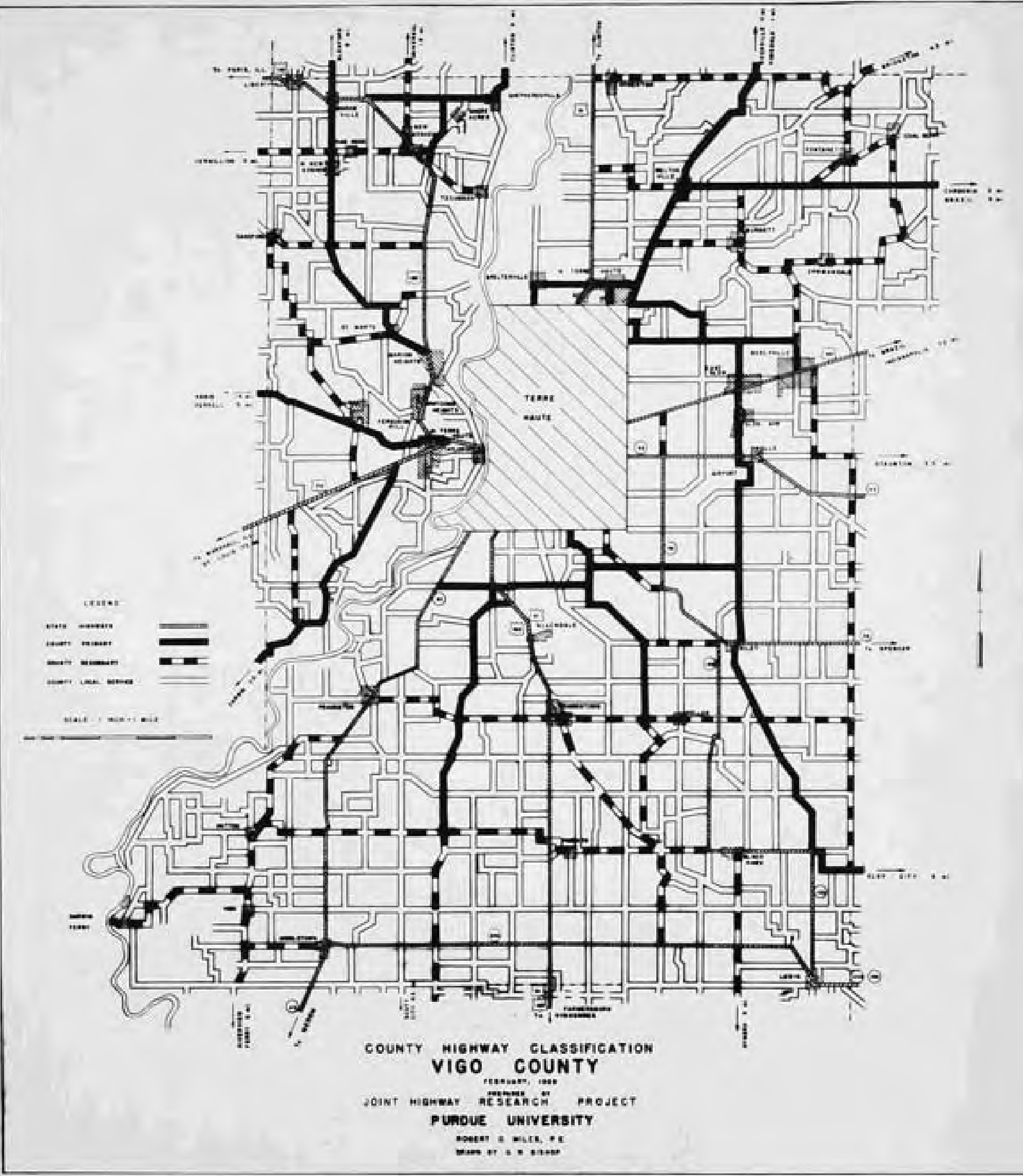

AN EXAMPLE OF COUNTY HIGHWAY CLASSIFICATION

FIGURE I 


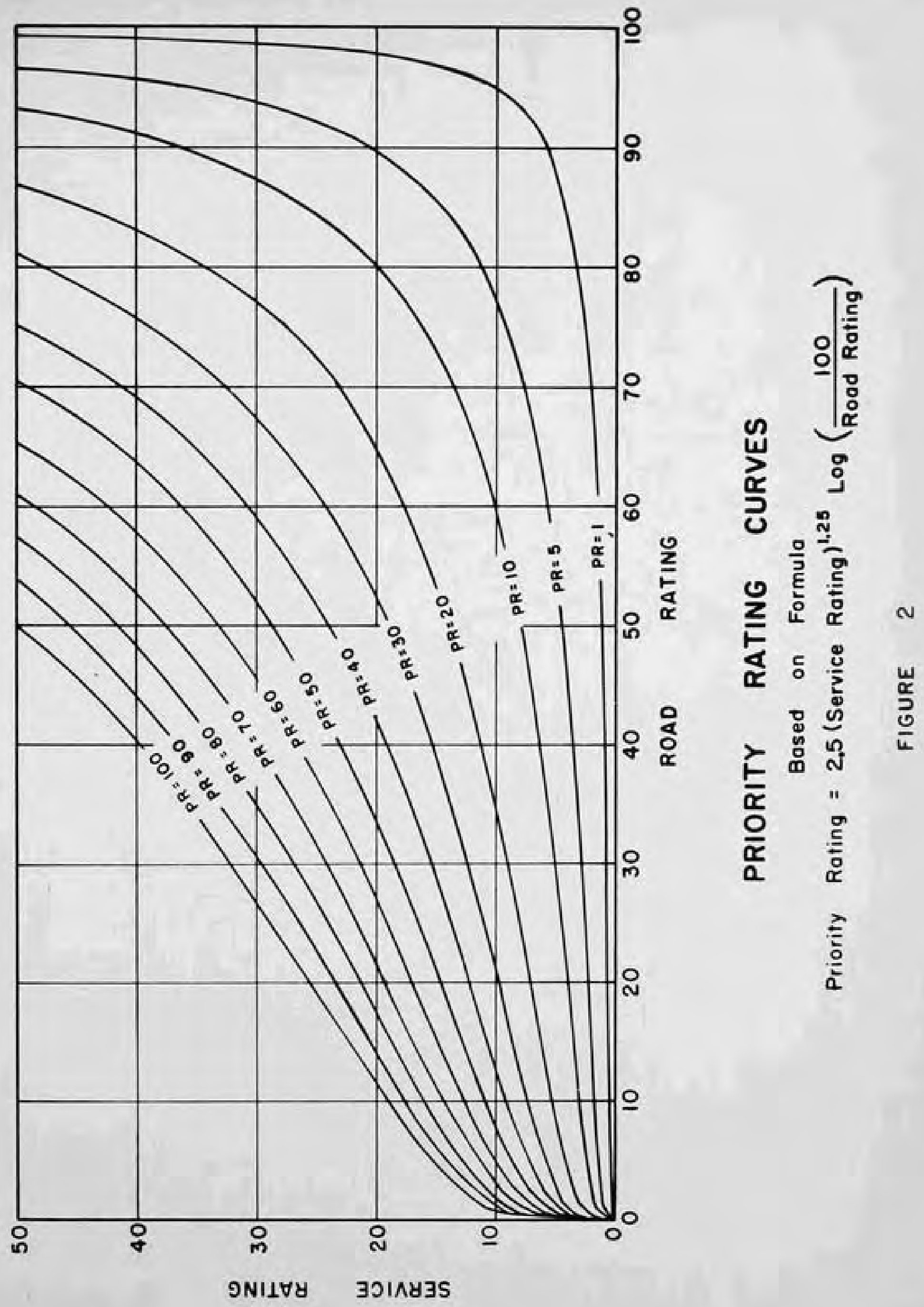




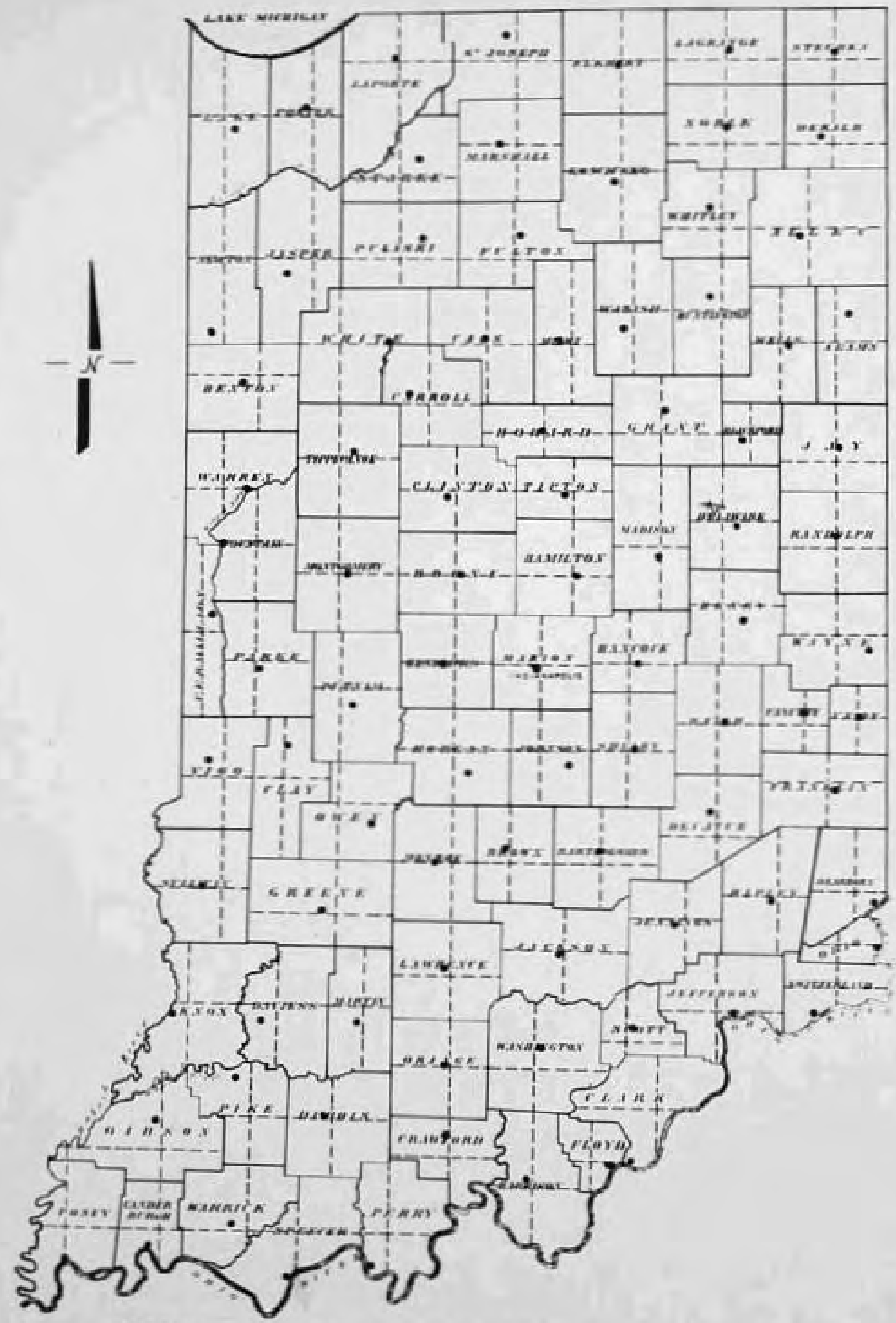
RECOMMENDED BASE LINES FOR RURAL ROAD MARKING SYSTEM 


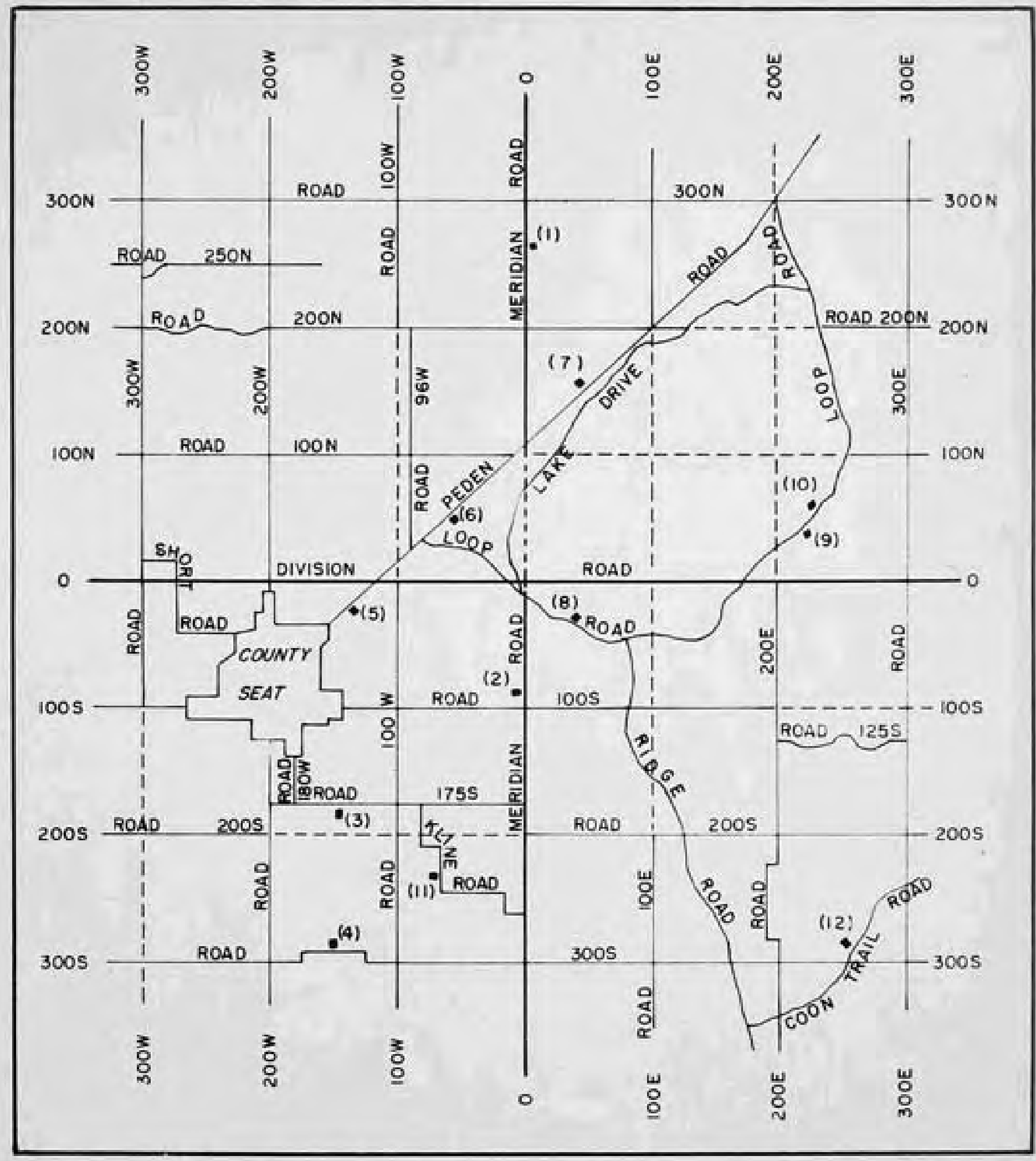

(I) 263 N MERIDIAN ROAD

(7) I5IN 43E PEDEN ROAD (OE)

(2) B8S MERIDIAN ROAD

(8) $28539 E$ LOOP ROAD (OE)

(3) 144W ROAD 175S

(9) $39 N$ N $222 E$ LOOP ROAD (ON)

(4) I5IW ROAD $300 \mathrm{~S}$

(10) 5 IN $230 E$ LOOP ROAD (ON)

(5) 2IS $134 W$ PEDEN ROAD (OS)

(II) $238569 \mathrm{~W}$ KLINE ROAD (I75S)

(6) $52 \mathrm{~N} 56 \mathrm{~W}$ PEDEN ROAD (OW)

(12) $2855252 E$ COON TRAIL ROAD (30OS)

EXAMPLES OF ROAD AND HOUSE DESIGNATIONS 